\title{
Reaching Sufis on the Spice Route: Sheikh Yusuf al- Makassari's Wanderlust 1644-1699
}

\author{
Abd. Karim ${ }^{1 *}$, Husnul Fahimah Ilyas ${ }^{2}$ \\ Balai Penelitian dan Pengembangan Keagamaan Makassar ${ }^{1}$ \\ \{karimsejarah@gmail.com ${ }^{1}$,husnullitbang@gmail.com ${ }^{2}$ \}
}

\begin{abstract}
The spice shipping and trading networks not only influenced political and economic conditions but also the formation of ulama networks. Archipelago scholars who traveled to deepen their religious knowledge were also within the network structure. This article aims to reveal the wandering of a Sufi, namely Sheikh Yusuf al-Makassari 1644-1699. This means that the spice route is the main factor supporting this ulama's journey. Syekh Yusuf is known as far as South Africa, giving an indication that this cleric used the spice route as a route to reach his magic. Starting from Makassar, Banten, Aceh, India, Yemen and Mecca he made his way. The question is how the journey and how it relates to the spice route. This article will look at this phenomenon using historical methods and philological approaches. The historical method is to reveal the process of Sheikh Yusuf's odyssey and a philological approach to explore Sheikh Yusuf's knowledge through his legacy manuscripts. The finding of this article is to see the spice network as a vessel for Sheikh Yusuf to reach Sufi. by looking at the pattern of the journey of Sheikh Yusuf's knowledge to various regions.
\end{abstract}

Keywords: spice route; ulama; Sufis; wandering

\section{Introdution}

Muhammad Syekh Yusuf Al-Makassari is known as a Sufi scholar who has a very high level of scholarship. Not only that, he is also known as a leading Islamic reformer in South Sulawesi and even in the archipelago. The people of South Sulawesi have great respect for Sheikh Yusuf, this can be seen from his grave which is never devoid of visitors. The tomb, which is located on Jalan Syekh Yusuf, Makassar City, is a place for pilgrims from all over the South Sulawesi region. Even during the Covid-19 pandemic, this tomb was never empty of visitors even though the quantity decreased.

According to one of the visitors to Syekh Yusuf's grave whom we met on August 5, 2020, all their descendants must have carried out this grave pilgrimage procession if they have carried out a major celebration such as weddings, weddings, pilgrimages and so on. They feel how important it is to visit this Tomb, even Covid-19 has not dampened their enthusiasm. This condition is quite natural because Syekh Yusuf is known as a very important figure in the history of the people of South Sulawesi. 
The full name of Sheikh Yusuf is Muhammad Syekh Yusuf bin Abdullah Abu al-Mahasin al-Taj al-Khalwati al-Makassary. He started studying in Islamic matters at the age of 8 in Bontoala. He obtained knowledge about Arabic language, jurisprudence, monotheism, tasawuf and logic from Sayed Ba 'Alwy bin Abdullah al-Allamah Thahir. Then when Syekh Yusuf was 15 years old, he studied from Sheikh Jalaluddin al-Aidit in Cikoang, Takalar Regency today.

Based on Hikayat Syekh Yusuf who came from H.S.D. Moentoe, Labbakang-Pangkajene (Tudjimah 1987: 1), Syekh Yusuf left for Banten, Syekh Yusuf's main goal was to deepen the religious knowledge that had previously been obtained in Cikoang. While in Banten he went to Jeddah on a British ship to study Islam in depth. Initially he studied with Abu Yazid then he was recommended to study with Sheikh Abd al-Qadir Jailani.

Furthermore, Azra's work (Azra 2013) describes a network of archipelago scholars including Sheikh Yusuf. It seems that Azra's work complements Tudjimah's work because Azra describes in detail the process of the ulama network being formed. For Syekh Yusuf's part, Azra has described how this cleric from South Sulawesi reached out of South Sulawesi, left for Banten, studied for Mecca, returned to Banten and was finally exiled to Sailon to South Africa. however, Azra has not explained the teachings of Sheikh Yusuf which contain the teachings of moderation.

Next, namely works (Muzdalifah et al. 2014) and (Sultan and Sahib 2006) are two works that are quite related because they were written directly by Syekh Yusuf's descendants based on lineage nazab. Both are descendants of Sheikh Yusuf. These two works also adequately explain how Sheikh Yusuf's journey from Sulawesi to South Africa. In addition, this paper also focuses more on the heroic studies of Syekh Yusuf during his life and the study of the teachings of the khalwatiah order of Syekh Yusuf. It's just that, the study of how Sheikh Yusuf's thoughts are especially related to religious moderation.

Abu Hamid's (Hamid. 2005) work is also one of the main references because this work is very detailed in describing the figure of Sheikh Yusuf in terms of his Sufism teachings and heroic stories. This work is in line with the studies of Azra, Muzdalifah and Sahib. The four works in sufficient detail describe the work of Sheikh Yusuf as a scholar and his teachings. However, the study of moderation has not been studied.

The work that uses local sources in South Sulawesi is lontara ', namely the work of H.A. Massiara and Djirong Basang. Both are works that tell Syekh Yusuf in the form of a saga. This work strictly uses local sources so that the presentation of this work is filled with stories with mystical narratives. The stories of his childhood and work in South Sulawesi are very clear. However, the matter of moderation in this work has not yet studied moderation in the teachings of Sheikh Yusuf.

Therefore, this research will reveal how Syekh Yusuf achieved his Sufi level by utilizing the Nusantara and Global spice routes. This means that deepening Islamic teachings requires access to transportation that connects other parts of the world, especially in Arab countries.

\section{Methods}

This study uses the historical method with a philological approach. The historical method is used to reveal the phenomena that occurred in the journey of Sheikh Yusuf. Starting from his journey from Makassar to Banten, Aceh, Rinir, Yemen, Damascus, Mecca and back to the archipelago. By using historical sources in the form of manuscripts, a philological approach is 
needed to read the contents of these sources. The sources obtained were in the form of saga and books by students as well as by Syekh Yusuf himself.

\section{Result}

The royal acceptance of Islam in South Sulawesi is supported by many factors, one of which is political factors, more precisely political conditions. Islam, which began to enter South Sulawesi in the 17th century, was not completely accepted by the kingdom. As previously explained, Islam was brought by three well-known datu ', namely datu' ri Bandang, Datu 'Patimang and Datu' ri Tiro. The three of them were the first scholars who succeeded in bringing and making major kingdoms in South Sulawesi embracing Islam.

Acceptance of Islam is of course influenced by political conditions. One of them is the acceptance of Islam in the Kingdom of Gowa. The kingdom of Gowa originally consisted of small areas led by a ruler. These areas are Buttono, Lakiung, Saumata, Parang-parang, Data ', Agang-Je'ne, Bisei and Kaliling (Patunru. 1982: 1). This area was the embryo of the Gowa Kingdom area which later transformed into a large area.

Some of these small areas were combined by Tomanurung. Tomanurung, who became the king of the nine regions, is believed to be the unifier of the often conflicting regions. Tomanurung in the mythology of the people of South Sulawesi is considered a person whose origin is unknown. Initially, the leaders of the nine regions agreed to form a council headed by a Paccallaiyya. The role of the chairman of this council is to resolve conflicts that occur between gallarang (rulers) but do not have full power over the resolution of these problems, so that sometimes problems are not resolved (Sewang 2005: 20).

In the midst of these conditions, a Tomanurung named Takak Bassia arrived. In various literature that tells of Tomanurung in Gowa, Takak Bassia is known as a princess from heaven who was sent to Gowa to become the leader of the nine Gallarang. It is estimated that the period of the appointment of the First King of Gowa occurred in the 14th century (Sewang 2005: 21).

As time went on, the Kingdom of Gowa grew even more when the Kingdoms of Gowa and Tallo merged into one. These two kingdoms merged into the Kingdom of Gowa-Tallo around 1528 (Poelinggomang 2016: 13) during the time of King of Gowa X I Mariogau Daeng Bonto Karaeng Lakiung Toni Pallangga Ulaweng and King Tallo Nappakata'na Daeng Padulung as King of Tallo (Sewang 2005: 23).

The formation of Makassar as a transit port in the archipelago and international networks made Makassar visited by many traders from various regions. Various nations visit Makassar because of its position as a trading city. Starting from the Arabs, Chinese and European Nations including Portuguese, Dutch, Spanish and many more.

The port of Makassar as a trading port creates opportunities for knowledge and cultural exchange. So trade does not only give birth to the exchange of merchandise. This made the Makassar region, in this case the power of the Gowa-Tallo Kingdom, become a cosmopolitan area in its era. This condition also provided an opportunity for the people and aristocrats in Makassar to get to know the new knowledge brought by traders. One of the scholars born during that period was Karaeng Pattingalloang.

Apart from Pattingalloang, during the same period a person who was thirsty for religious knowledge was born. The scholar was known as Sheikh Yusuf. He was born on July 3, 1926 (Paramma 2007: 29) when the Gowa Kingdom conquered Bima, Dompu, Sumbawa, and 
Kengke (Cummings 2007: 240). This figure is known as a scholar who had a great influence on the development of Islam. What is quite interesting is that between Karaeng Pattingalloang and Sheikh Yusuf became two scholars who lived during the same period, meaning that the Gowa-Tallo Kingdom had two important scholars.

\section{Discussion}

Sheikh Yusuf's odyssey in the spice route began when he left for Banten in 1644. In his learning process in Banten, Yusuf was finally sent by the kingdom to interpret a teaching of Hamzah Fansuri to Syekh Nuruddin Ar-raniri who was in Aceh (van Bruinessen 1995: 182) . Yusuf and several scholars in Banten finally made an expedition to Aceh. However, Syekh Yusuf did not meet Arraniri in Aceh because in the same period Arraniri had been replaced by Saif al-Riyal as a religious advisor (Gibson 2012: 68). Arraniri's replacement practically required him to return to his native India / Gujarat.

The return of Arraniri Gujarat finally made Sheikh Yusuf continue his expedition to Gujarat to study from him. From this teacher, Sheikh Yusuf received a certificate from the Qadariyyah Order. In this way, Sheikh Yusuf has added his Knowledge, especially at the Tarekat level. Regarding Syekh Yusuf's meeting with Arraniri, several sources said that they met in Aceh. However, if the year Arraniri left for Rinir, India and the period of Sheikh Yusuf's arrival, they did not meet in Aceh. Arraniri left Aceh around 1644, while the Syekh Yusuf period was in Banten around 1644-1645. This indicates that Syekh Yusuf met Arraniri in India not in Aceh.

After studying at Rinir, India Sheikh Yusuf continued his journey to Yemen. He finally studied with Sheikh Abi Abdillah Muhammad Abdul Baqi bin al-Kabir Mazjaji al-Yamani Zaidi al-Naqsyabandy and obtained the Naqsyabandiyah diploma (Hamka 2009: 131). Then Sheikh Yusuf continued his journey to Zubaid to meet Sheikh Maulana Sayyid Ali and learn Baalawiyah dance (Paramma 2007: 32).

Sheikh Yusuf's journey eventually went to Makkah, to perform the Hajj. In Syekh Yusuf's saga, it is said that Tuanta Salamaka visited Mecca in addition to Hajj and also wanted to make a pilgrimage to the Prophet's grave in Medina. In the story, it is described something which is quite interesting because Tuanta tilted the position of the Ka'bah because it was not allowed to enter the Grand Mosque (Hikayat Tuanta Salamaka). This story cannot be fully trusted scientifically, however, what you want to describe is that Sheikh Yusuf was a scholar who had a special place in the eyes of the people of Mecca at that time.

After carrying out the haj pilgrimage, Sheikh Yusuf continued his educational journey by studying with Sheikh Burhanuddin Al Mulla bin Syekh Ibrahim bin al Husain bin Syihabuddin Al Kurdi Al Kaurani Madani and obtained a diploma in the Syattariyah Tarekat (Ali 2016: 14) (Hamka 2009: 131). Al-Kaurani is also the teacher of Abd al-Rauf al-Sinkili (Ali 2016: 14).

Furthermore, Sheikh Yusuf continued his journey to Damascus and studied at Ayyūb ibn Ahmad ibn Ayyūb al-Dimashqī al-Khalwatī (Ali 2016: 14). It was through this teacher that Sheikh Yusuf was given the title Taju'l Khawati Hidayatullah (Hamka 2009: 132). This tarekat was later known in South Sulawesi, especially in the territory of the Kingdom of Gowa as a legacy from Sheikh Yusuf.

When examined from the process of Sheikh Yusuf's long journey in studying, he really became the unifier between continents that were quite far apart. Tuanta's educational history also clearly illustrates that he succeeded in studying 16 schools of Tarekat namely 
Dasuqiyyah, Syaziliyyah, Hasytiyyah, Rifaiyyah, al-Idrusiyyah or al-Sanusiyyah, Suhrawardiyyah, Makhdumiyyah, Kubrawiyyah, Maulawiyyah, Madariyyah, even to Thariqat Ahmadiyyah 10 September 2020). Moreover, after studying in an Arab country, Sheikh Yusuf finally returned to the archipelago and settled in Banten in 1669 (Paramma 2007: 34). At the same time, the Kingdom of Banten was ruled by a friend of his own who had the title Sultan Ageng Tirtayasa.

\section{Conclusion}

Sheikh Yusuf's journey in reaching the Sufi level is evident by looking at the pre-formed trading network. Whereas, the Spice Route is a great place for Sheikh Yusuf or the Archipelago's scholars to travel and wander about knowledge. Without the spice route, the Arabs would not reach the archipelago, without the Arabs, Islam would not be known in other words, the spice network did not only unite humans but also Islamic knowledge, in this case the side of religiosity.

\section{References}

[1] Ali, Abdul Kun. 2016. “AL-MAKASSARI'S (1626 -1699) THOUGHT ON ALINSANAL-KAMIL IN 17TH CENTURY.” Universiti Teknologi Malaysia.

[2] Azra, Azyumardi. 1998. Esei-esei intelektual Muslim dan pendidikan Islam. Jakarta: Logos Wacana Ilmu.

[3] Azra, Azyumardi. 2013. Jaringan ulama: Timur Tengah \& kepulauan Nusantara abad XVII \& XVIII : akar pembaruan Islam Indonesia.

[4] van Bruinessen, M. M. 1995. "Sharia Court, Tarekat and Pesantren: Religious Institutions in the Banten Sultanate."

[5] Cummings, William. 2007. "Islam, Empire and Makassarese Historiography in the Reign of Sultan Ala'uddin (1593-1639)." Journal of Southeast Asian Studies 38(2):197-214.

[6] Gibson, Thomas. 2012. "Narasi Islam Dan Otoritas Di Asia Tenggara Dari Abad Ke 16 Hingga Abad Ke 21."

[7] Hamka. 2009. Dari perbendaharaan lama. Shah Alam: Pustaka Dini.

[8] Paramma, Djamaluddin Aziz. 2007. Syekh Yusuf Al Makassary: putra Makassar. Makassar: Nala Cipta Litera.

[9] Patunru., Abdul Razak Daeng. 1982. Sedjarah Gowa. Salt Lake City, Utah: Memfilmkan oleh Genealogical Society of Utah.

[10] Poelinggomang, Edward L. 2016. Makassar Abad XIX. Kepustakaan Populer Gramedia.

[11] Sewang, Ahmad M. 2005. Islamisasi Kerajaan Gowa : abad XVI sampai abad XVII. Jakarta: Yayasan Obor Indonesia.

[12] Tudjimah. 1987. "Syekh Jusuf Makasar : riwayat hidup, karya, dan ajarannya." 